\title{
The theoretical bases and determination general laws of tuxedo design Evdushchenko E. ${ }^{1}$, Fedorova A. ${ }^{2}$ Теоретические основы и установление общих закономерностей проектирования смокинга

\author{
Евдущенко Е. В. ${ }^{1}$, Федорова А. Ю.
}

\author{
${ }^{1}$ Евдущенко Елена Владимировна / Evdushchenko Elena - кандидат технических наук, дочент, \\ кафедра конструирования и технологии изделий легкой промышленности; \\ ${ }^{2}$ Федорова Александра Юрьевна / Fedorova Aleksandra - студент, \\ художественно-технологический факультет, \\ Институт дизайна и технологий \\ Омский государственный технический университет, г. Омск
}

\begin{abstract}
Аннотация: в статье описываются история происхождения смокинга в гардеробе мужчин и его отличительные особенности. Дана ретроспектива проектирования женской одежды под влиянием исторических событий. Новаторское влияние актрис и модельеров в середине двадиатого века привело к появлению смокинга в женском гардеробе.

Abstract: the article describes about the history of the tuxedo origin in the men wardrobe, and its distinctive features. It was performed a retrospective design of women's clothing under the influence of historical events. Innovative influence actresses and fashion designers led to a tuxedo in the female clothes in the middle of the twentieth century.
\end{abstract}

Ключевые слова: смокинг, женский брючный костюм, мужской гардероб.

Keywords: tuxedo, a pantsuit for women, men's wardrobe.

Сегодня всем известен костюм под названием «смокинг». Мы наблюдаем на экранах телевизоров, на фото в модных журналах и в интернете знаменитых мужчин в этом элегантном и эффектном наряде. Когда-то он являлся частью лишь мужского гардероба, но сейчас этот стильный костюм используют и женщины.

Значение слова смокинг по словарю Ушакова: «пиджак черного сукна с открытой грудью и длинными, обычно обшитыми шелком, лацканами» [4].

К смокингу полагаются тугая крахмальная манишка, стоячий воротничок с загнутыми углами, чёрный галстук-бабочка, ботинки из тонкой кожи, но не лакированные, чёрный жилет или пояс-кушак камербанд (cummerbund).

B XVII веке в Англии появляется табак и курение быстро набирает популярность. На встречах и балах высшего общества неподалеку от основного зала имелись специальные комнаты для курения, в которые удалялись мужчины, так как правила не позволяли курить в присутствии дам. Чтобы не переносить запах табака из курительной комнаты, входя туда джентльмены надевали специальные "smoking jacket", а уходя, снимали их.

Смокинг отличался от пиджака тем, что лацканы изделия выполнялись из атласа. Связано это также с его практическим применением, а именно: в то время было верхом неприличия стряхивать пепел с сигары, то есть столбик пепла должен был упасть произвольно, поэтому он часто оказывался на костюмах мужчин. Дабы пепел не оставил следов, были придуманы атласные лацканы, с которых он стряхивался легко и бесследно.

История появления смокинга в мужском шкафу интересна, но и не стоит забывать, что у женщин он также присутствует. В настоящее время женщина, облаченная в брюки или брючный костюм, выглядит привычно, однако несколько десятков лет назад дамы не могли носить брюки в общественном месте, это считалось плохим тоном. Но время все меняет; меняются потребности, возможности, мысли, взгляды, меняется все общество.

Первоначально возникновение женских брюк обусловлено удобством и природными условиями, поэтому первыми надели штаны женщины варварских племен, Геродот в свою очередь утверждал: Амазонки «носят одежду, одинаковую с мужчинами». Также в некоторых странах Востока различные модели брюк всегда были частью женского костюма. Но в Европе на рубеже XIX-XX этот тип одежды принадлежал лишь мужскому полу и возможно первой, кто надел брюки, была Жанна Д’Арк.

Внедряются брюки в женскую европейскую моду только в конце XIX века. Связано это с изобретением велосипеда и развитием спортивной культуры. Женщины того времени с удовольствием разъезжали по улицам на велосипеде и специально для комфорта надевали бриджи, заканчивающиеся лентой под коленом, сверху широкая юбка, а под бриджи - чулки.

В 1914 году началась Первая мировая война и женщины были вынуждены заменить мужчин в управлениях и на производстве. Поскольку в цехах было невозможно работать в корсетах и в длинных 
юбках, то дамам было разрешено переодеваться в рабочие часы в комбинезоны и бриджи. Позже женщины оценили удобство брюк и стали внедрять данный предмет одежды в уличную моду. Брюки понемногу овладевали высшими позициями дамского гардероба [2, с. 50].

Женская фигура стала совсем иной - исчезли пышные формы, а бюст и бедра значительно уменьшились. В начале 20 века преобладает стиль «модерн» с его простотой форм и лаконичностью линий. Происходит постепенный переход из мужского гардероба в женский смокингов, брюк «гольф» и даже пижам. Женщины позволяют себе короткие стрижки, яркий макияж, и они, не стесняясь, курят сигару.

Жакет был заимствован из мужской одежды гораздо раньше брюк, а его прототипы впервые встречаются в 16 веке во Франции, Италии и Англии. Но лишь в конце 19 века женский жакет стал широко распространяться в женском гардеробе, первым, кто изготовил его, был английский портной, он сшил жакет для принцессы Уэльской, будущей жены короля Англии Эдуарда VII. Постепенно костюм, состоящий из юбки и жакета, появился у каждой женщины.

В 1930-х гг. такие костюмы стали основой гардероба дам. Девушки с удовольствием надевали жакеты как на прогулку, так и на торжественные вечера, комбинируя с юбками и платьями. Жакет 1930-х был двух типов - короткий и утянутый в талии или длинный (до середины бедра) и повторяющий изгибы тела. Костюм 30-х годов - самое элегантное изобретение XX века, которое до сих пор вдохновляет дизайнеров на создание изысканных образов.

Приближается 1933 год, знаменитая актриса Марлен Дитрих носит брюки как рабочую одежду во время съёмок, другие звезды следуют ее примеру. Мода на брюки началась, хотя несла некий авангард.

В начале XX века в мире моды появляется великая Габриэль «Коко» Шанель, которая впервые облегчает женский гардероб от традиционных условностей и пропагандирует практичную элегантность. «Я создаю одежду, в которой женщина может существовать, дышать, чувствовать себя удобно и выглядеть моложе»,- говорила Шанель. Она продолжает внедрять брюки и предметы мужского в женское.

К 40-м годам брюки ушли на второй план, вновь были надеты платья, женственность заняла первое место. Тем не менее, костюм по-прежнему оставался в женском шкафу, позволял выглядеть в нем собранно и дисциплинированно, но общие пропорции его были слишком жесткими, «квадратными». Жесткие послевоенные ограничения на количество расходуемого при пошиве одежды материала привели к появлению в моде узких женских брюк с минимумом декоративных деталей, а зачастую и вовсе без них. Брюки «потеряли» даже складочки, отвороты, клапаны и карманы.

Также стремление девушек вступать в ряды военных, привело модельеров к задумке создания форменной и псевдо форменной женской одежды. Эльза Скиапарелли создала практичный брючный костюм «для боевой тревоги», который застегивается на «молнию».

После войны женщины с удовольствием переоделись в женственные нарядные платья с узкой талией, покатыми плечами и пышной юбкой, предложенные им Кристианом Диором. Это не означает, что костюм исчез из женского гардероба.

В 1950-х испанский модельер Кристобаль Баленсиага создал костюмы для женщин любого типа фигуры. Он разрабатывал одежды из материалов, хорошо держащих форму, в моделях преобладали минимализм и изысканность. Поклонник рукава-реглан и цельного кроя, Баленсиага создавал строгие и даже деловые костюмы нетрадиционной конструкции и пропорций [1, с. 24].

В шестидесятых Андре Курраж также изобрел брючный костюм, подобный футуристическим одеждам по мотивам космических путешествий. Курраж, понимая мысли молодых женщин, предлагал им одеваться в костюмы геометрических форм, сшитые из ослепительно белых тканей. Узкие брюкидудочки вошли в молу после моделей Андре Курража.

Ив Сен-Лоран - один из главных дизайнеров XX века - открыл собственный Дом моды в 1961 г. С этого момента он постоянно пополнял копилку моды все новыми и новыми версиями традиционных вещей. С этого времени его творчество было направлено на преобразование традиционных вещей. Им был возрожден классический тренч и костюм сафари, бархатный костюм с бриджами. Именно Ив СенЛоран показал на подиуме в 1966 г. женский смокинг.

Ив Сен-Лоран неожиданно предложил носить женщинам смокинг с элегантными брюками вместо вечернего платья. Этот факт считается началом легализации женского городского костюма с брюками. На протяжении всех 1970-х женский брючный костюм активно носился как знаменитостями, так и рядовыми сотрудницами офисов, превратившись в элегантную униформу работающих женщин [3, с. 9].

В настоящее время брючный костюм имеется практически у каждой женщины. Сдержанные варианты, чаще нейтральных оттенков и стандартного кроя, надевают на работу; яркие, экстравагантные с необычным декором и конструкцией - на торжественные мероприятия и вечера. Брючный дамский костюм - излюбленное поле для знаменитых дизайнеров, в работе с костюмами есть, где развернуться буйной фантазии. Что касается смокинга, он сейчас считается стильным и модным предметом женского гардероба, за счет различных силуэтов, каждый смокинг создает индивидуальный образ, поэтому любая 
девушка может найти желаемое. И кто бы мог подумать, что когда-то столь практичная мужская вещь станет модным атрибутом для женщин и неотъемлемой частью гардероба для мужчин.

\section{Лumepamypa}

1. Баландина E. A. Получение сложных пространственных форм в одежде // Проблемы современной науки и образования. Издательство: Олимп (Иваново), 2016. № 10 (52). С. 23-26.

2. Виниченко И. В. Женская история: современные проблемы исследования // Проблемы современной науки и образования. Издательство: Олимп (Иваново), 2016. № 10 (52). С. 50-51.

3. Виниченко И. В. Модные образы и общество: традиции и новые реалии // В мире науки и искусства: вопросы филологии, искусствоведения и культурологии. Издательство: Ассоциация научных сотрудников «Сибирская академическая книга», 2015. № 54. С. 7-12.

4. Смокинг. Толковый словарь Ушакова. [Электронный ресурс]: Полный токовый словарь русского языка. Режим доступа: http://ushakovdictionary.ru/word.php?wordid=71489/ (дата обращения: 19.10.2016). 